\title{
Revitalization of East Nusa Tenggara Traditional Dance through Identification and Inventory as Protection to Indonesia Culture
}

\author{
Olivia de Haviland Basoeki ${ }^{1}$, Eka Dyah Puspita Sari ${ }^{1}$, Rulli Saragi ${ }^{1}$ \\ \{oliviabasoeki34@gmail.com, ekadyah.mail@gmail.com, rullysaragi93@gmail.com\} \\ Politeknik Negeri Kupang ${ }^{1}$
}

\begin{abstract}
East Nusa Tenggara has rich and various cultural heritages, but it is indeed neglected, displaced, and ignored. The treatment and retention way, as a main part to sustain the culture, is also poor. Dealing with the problem, higher education plays a role to keep nation's culture. Regarding that, the problem of this paper is how the identification, inventory, and ease of access process of traditional dance in East Nusa Tenggara are conducted. The specific aim of this paper is to identify the traditional dance of East Nusa Tenggara, to invent and process nation's culture in form of traditional dance of East Nusa Tenggara so it stays original as it is, and to make easy access for the people, both domestic and international people, to access nation's culture collection, especially traditional dance in East Nusa Tenggara. Qualitative research method is applied in this paper to get data of traditional dance in East Nusa Tenggara. The data are collected through identification of the dance, starting from the form, starter, and function. Then, the data are gathered through some steps, i.e. observation, video recording, photo taking, and interview with the related parties about the dance. The plan of this research is by doing field observation, dance identification, dance inventory, and East Nusa Tenggara traditional dance documentation. The result of this research is mini encyclopedia of East Nusa Tenggara traditional dance that is original and easy to be accessed by the society.
\end{abstract}

Keywords: East Nusa Tenggara, encyclopedia dance, traditional dance

\section{Background}

Indonesia is well-known by its various cultures. Those cultures make Indonesian civilization vary. One of the cultures is traditional dance in each region in Indonesia. The traditional dance draws real picture of a region's life, so it can be said that the traditional dance mark as a symbol of civilization of each region. Traditional dance is also performed during traditional celebration of region. But, the dance is getting faded, or in other words, it is almost extinct due to rapid growth of time [1].

East Nusa Tenggara also has various traditional dances that spread out in some big islands, such as Flores, Alor, Timor, Sumba, and Sabu. Each island has specific show art related to its traditional celebration. Yet, along with the rapid growth of time, the traditional dance is not inherited well to the next generations. The change and growth of time makes existing traditional dance faded. Traditional art of East Nusa Tenggara is currently in the edge of extinction limit. It may happen because there is no interest in young generations which causes traditional art is slowly had forgotten [2] 
The existing of Law No. 4, 1990 that relates to the effort to sustain nation's asset on retention of printed art and recorded art. Higher education plays a role to keep nation's culture, especially on traditional dance of East Nusa Tenggara which is almost extinct. Printed art and recorded art as recording of human science can function as source of learning, research, information of various science field and cultural recreation. Printed art and recorded art of a nation are records of the nation knowledge and also part of records of human knowledge [3]

\section{Method}

Qualitative research method was used to gather data of traditional dance in East Nusa Tenggara through dance identification, starting from the form, beginning, and function of traditional dance in East Nusa Tenggara. Types of data used were primary and secondary data. Primary data were obtained directly by the writers through observation, video recording, photo taking during the performance of the dance, and interviewing with the related parts on the dance. The analysis of the data was done after compiling all data needed. The data were categorized first in this step, then they were analysed until this research came into conclusion and exposed answers of the problems.

\section{Discussion}

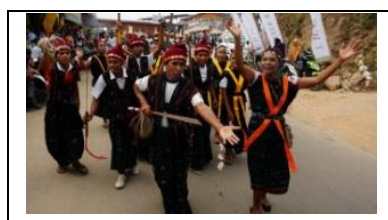

Ja'i Dance (Ngada Tribe-East Nusa Tenggara)

Ja' $\mathrm{i}$ dance is a traditional dance of Ngada people in Flores,

East Nusa Tenggara. This dance is a group dance as a symbol

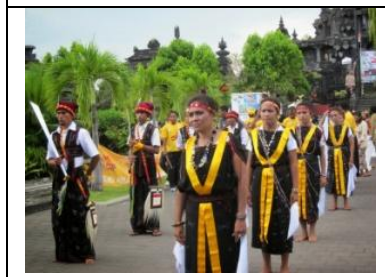

of gratitude and happiness. This dance is a well-known

traditional dance in Flores, especially on Ngada people. It is

also often performed on various events, such as celebration,

traditional celebration, and welcoming honorable guest [4].

\section{Function and Meaning of Ja'i Dance}

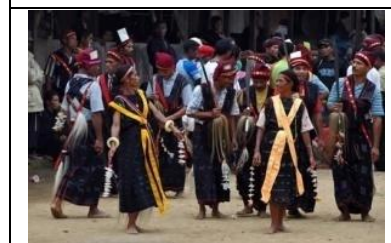

Ja'i dance is a well-known dance on traditional celebration as a symbol of gratitude and happiness. For Ngada people, Ja'I

dance also has some important values, both in social and

community life. We can clearly see how the spirit of togetherness in the dance. 

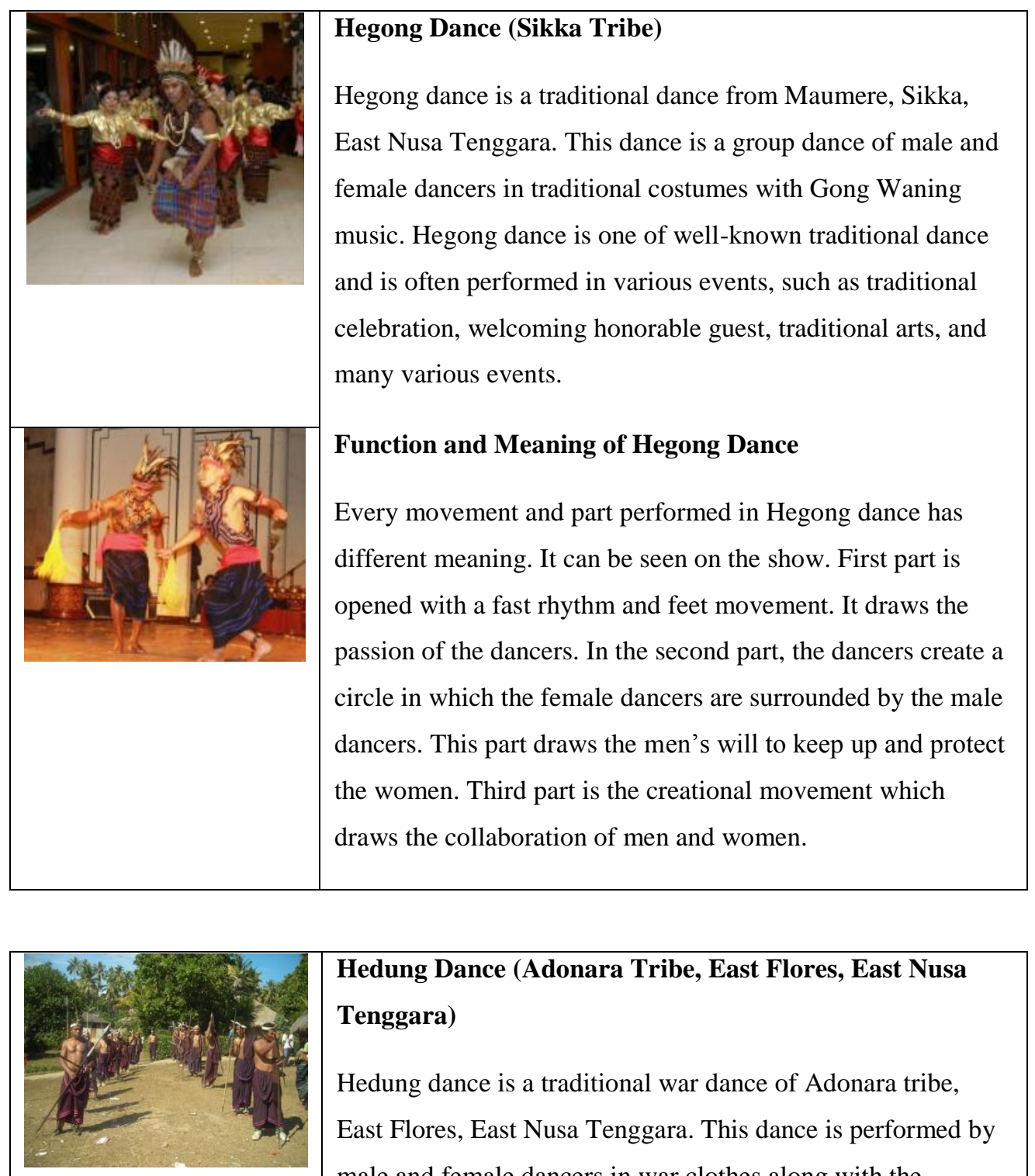

Hedung Dance (Adonara Tribe, East Flores, East Nusa Tenggara)

Hedung dance is a traditional war dance of Adonara tribe, East Flores, East Nusa Tenggara. This dance is performed by male and female dancers in war clothes along with the weapon. In the show, they dance in movement which draws heroic passion of Adonara tribe in battle field. Hedung dance is one of well-known dance and is often performed in various events, such as welcoming honorable guest, traditional 


\begin{tabular}{|l|l|} 
Hedung dance is originally a war dance and a part of \\
traditional ritual of Adonara tribe in taking and welcoming \\
heroes from the battle field. Hedung dance is now used by the \\
Adonara tribe as a respect to the ancestors. Besides that, this \\
dance is also functioned to introduce and commemorate to the \\
young generations of their tradition, art, and heroic spirit.
\end{tabular}

Rangkuk Alu Dance (Manggarai Tribe)
Rangkuk Alu dance is created through the inspiration of
traditional game of Rangkuk Alu or Rangku Alu. Rangkuk
Rangkuk Alu dance is one of traditional dance from
Manggarai, Flores, East Nusa Tenggara.




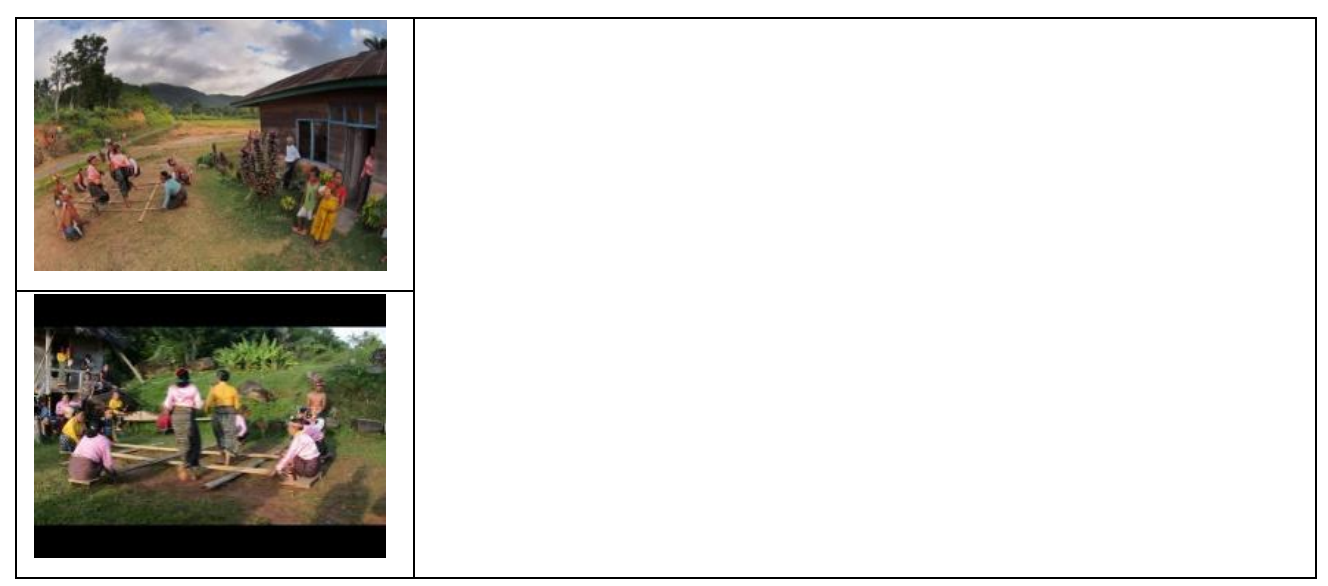

\begin{tabular}{|l|l|} 
This traditional dance is a group dance from Ende, Flores, East \\
Nusa Tenggara. Gawi dance is one of traditional dance from \\
Ende-Lio tribe as a gratitude for all blessings from God. In the \\
performance, Gawi dance is performed in group by holding \\
hands and creating circle formation which makes it as the \\
characteristic of the dance. \\
Function and Meaning of Gawi Dance \\
This dance functions as gratitude and respect to the God. Besides \\
spiritual and historical values, this dance is also rich in \\
philosophical value. One of them can be seen in the form of the \\
dance in which the dancers hold hands and create circle \\
formation.
\end{tabular}




\begin{tabular}{|c|c|}
\hline 61 & $\begin{array}{l}\text { Todagu Dance (Boawae, Nagekeo Regency) } \\
\text { Todagu dance is a name of a traditional dance in Boawae } \\
\text { tribe, Nagekeo regency. It is named Toda Gu because the } \\
\text { dance musical instrument uses drum (Toda) and bamboo } \\
(\mathrm{Gu}) \text { which are hit in tone and rhythm into one package of } \\
\text { movement and dance expression. It is the reason why the } \\
\text { dance is called Toda Gu. } \\
\text { Function and Meaning of Todagu Dance } \\
\text { The dance main meaning is as expression of masculinity and } \\
\text { agility in protecting nation or all the wealth. The tool used to } \\
\text { balance feet movement is spear (Bhuja) and sword (Topo). } \\
\text { Regarding the tool and the movement, all dancers in this } \\
\text { dance are male. }\end{array}$ \\
\hline
\end{tabular}

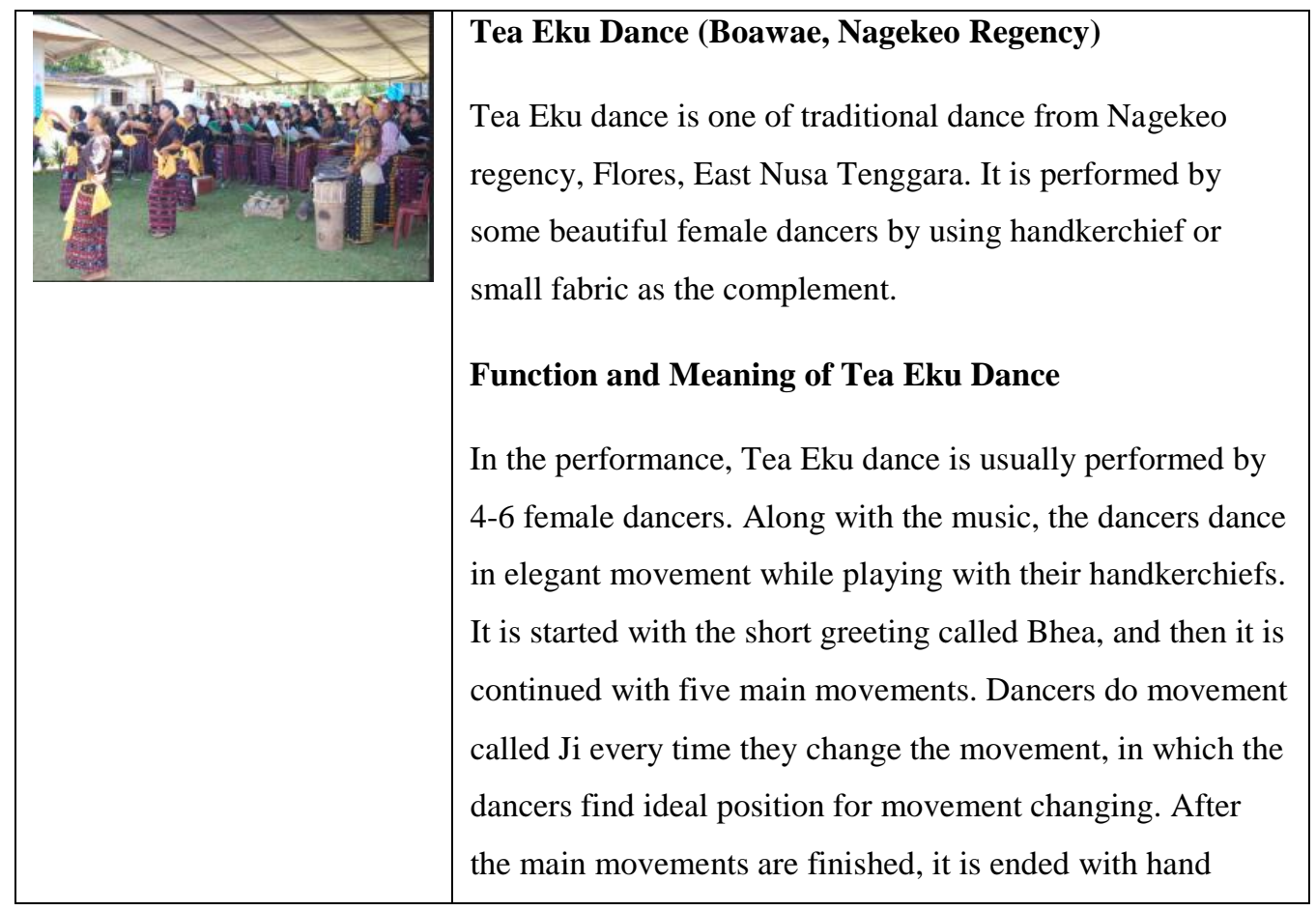




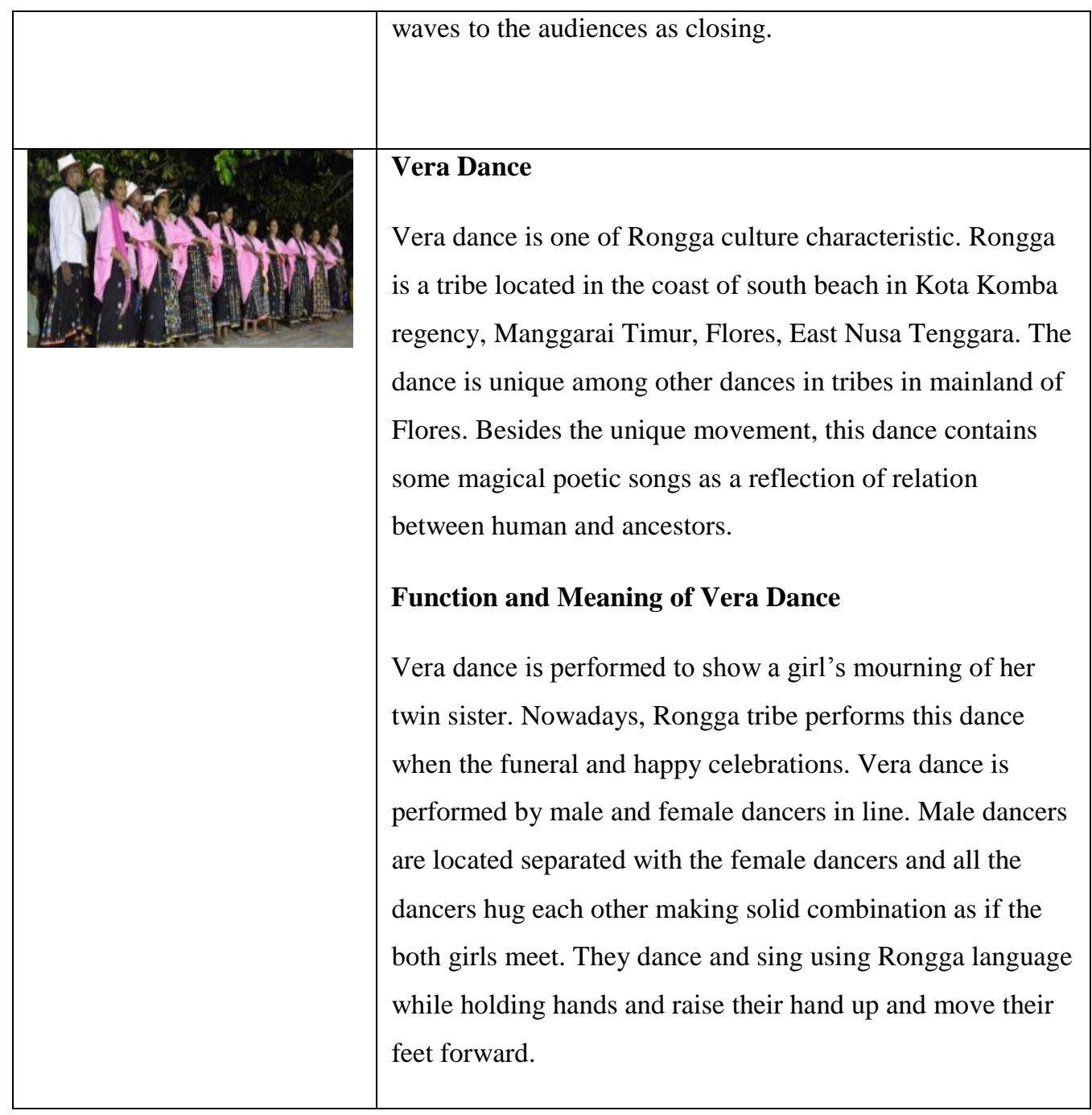




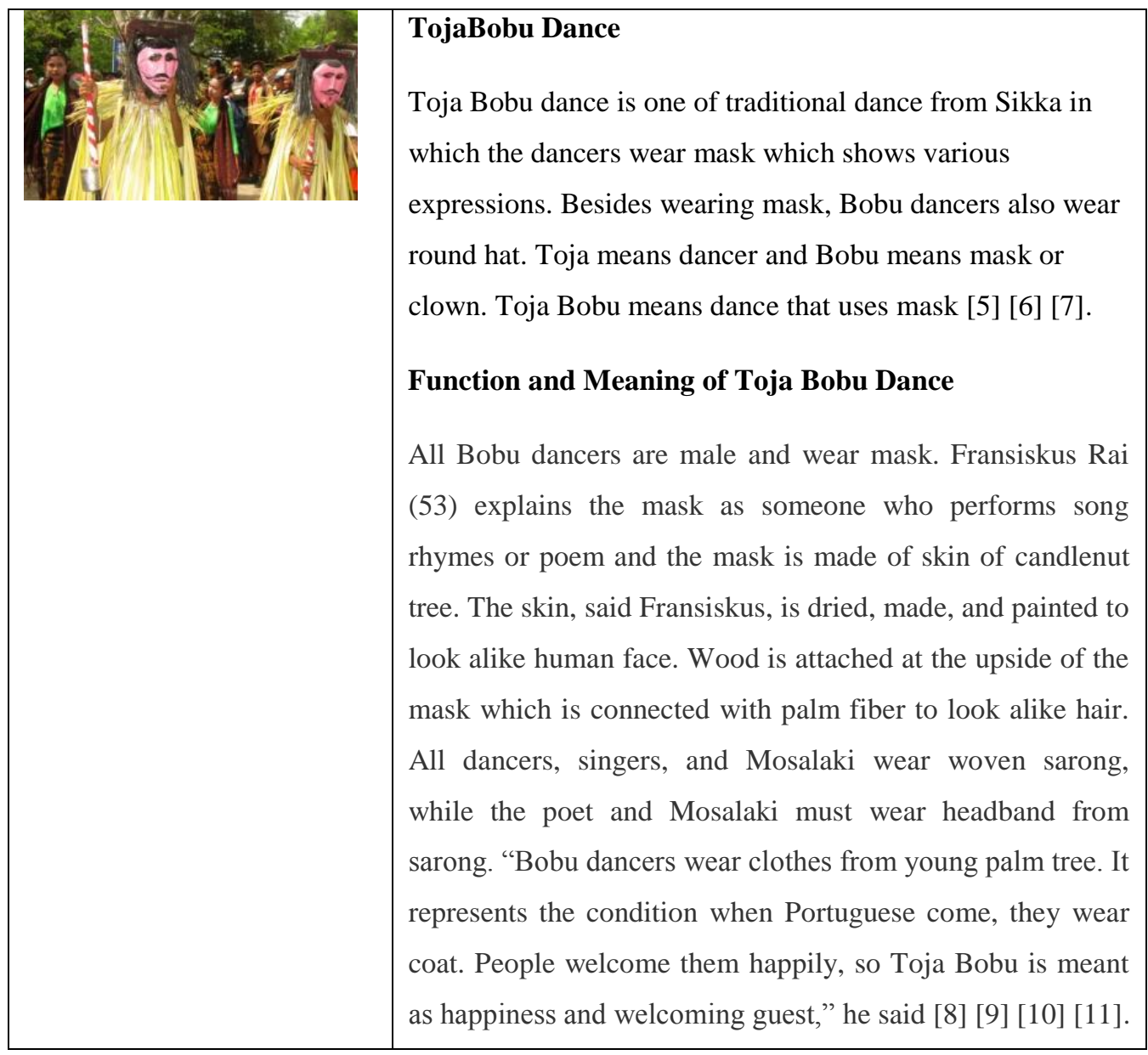

\section{Conclusion}

Traditional dance in Flores is almost the same as other traditional dances. The dance represents gratitude, war dance makes fighting spirit of the heroes higher and welcomes the heroes from the battle field, poetic song sounds magical as a reflection of relation between human and ancestors or a reflection of traditional game.

\section{References}

[1] Bandem, I Made. 1983. Ensiklopedi Tari Bali. Denpasar: Asti Denpasar

[2] Bastomi,Suwaji. 1992. Wawasan Seni. Semarang: IKIP Semarang Press

[3] Barker, Chis. 2005. Cultural Studies: Teori dan Praktek. Yogyakarta. PT Bentang Pustaka 
[4] Djokaho, Margareth Elizabeth. 2013. Pergeseran Fungsi Tari Ja'i Dari Ritual ke Profan di Kota Kupang. Universitas Pendidikan Indonesia

[5] Djelantik, AAM. 1999. Estetika Sebuah Pengantar. Bandung: Masyarakat Seni Pertunjukkan Indonesia

[6] Ferdinand Kerebungu. 2010. Pengembangan Industri Pariwisata Budaya dalam Meningkatkan Pendapatan Asli Daerah. Manado

[7] Hadi, Y Sumandiyo. 2005. Sosiologi Tari. Yogyakarta: Pusat Yogyakarta

[8] Ni Wayan, Ekaliani. 2011. Tari Legong Sembah Bintang di Desa Bangle Karangasem. Abstract. Documentation ISI Denpasar

[9] Novrizal,Fasa. 2009. Perlindungan Karya Cipta Seni Tari. Tesis. Universitas Diponegoro Semarang

[10] Sedyawati,Edi. 1981. Pertumbuhan Seni Pertunjukan. Jakarta: Sinar Harapan

[11] Widyarto Rinto,dkk. 2007. Inventarisasi dan Dokumentasi Seni Pertunjukan Tari di Nusa Tenggara Barat. Abstract. Documentation ISI Denpasar 